\title{
Jean Rhys's Tropographies: \\ Unmappable Identity and the Tropical Landscape in Wide Sargasso Sea and Selected Short Fiction
}

Jessica Gildersleeve

Griffith University

\begin{abstract}
This essay seeks to trouble the traditional understanding of Jean Rhys's 'homelessness' through a re-examination of the way in which the uncertain identities of her fiction are tied to their geographical settings. This works towards a reading of Rhys's narratives as 'literature of the tropics,' describing not only the landscape within which and from which so many of them operate, but a literature of the unrecognised, the unmapped. In this essay I seek to complicate traditional readings of Rhys's work that reassert her liminality and sense of unbelonging to propose that it is, paradoxically, the affinity of her work with the unassimilable tropics that produces this 'outsider status.'
\end{abstract}

$\mathrm{I}^{\mathrm{t} w \mathrm{sin}}$ f the fundamental task of postcolonial criticism is, as Robert J. C. Young puts it, to 'find a way to talk about' the feeling that 'you [are] not the subject of your own sentence,' that you are always already 'spoken for,' or 'the object of speech,' that 'you live in a world of others, a world that exists for others' (1), then it is inarguable that Jean Rhys's writing - her novels, short fiction, and life writing - figures a performance of this sense of being 'outside,' perpetually 'Othered.' It is not clear how one should best describe Rhys: as Dominican, English, French? Simply, Creole? How simple can that be? Even Rhys herself remained ambivalent about her racial identity; 'as far as I know,' she wrote in a 1959 letter to Francis Wyndham, 'I am white - but I have no country really now' (Wyndham and Melly 172). Antoinette Cosway, the protagonist of Rhys’s 1966 novel Wide Sargasso Sea, echoes this sentiment: 'between you I often wonder who I am and where is my country and where do I belong and why was I ever born at all' (64). And in the short story 'I Used to Live Here Once' (1976) this tenuous grasp on place is taken so far that the narrative can only figure its protagonist as a ghost, unseen by the inhabitants of her tropical island home. The narrator's conclusion, 'That was the first time she knew,' at once works to confirm the protagonist's spectrality, and the sense in which she was always already less 'real' than, unclaimed by, the land (Rhys, Sleep it Off, Lady 176). The instability of Rhys's own national identity means that most criticism on Rhys's work describes the gendered and racialised discourses of her narratives as figuring a sense of 'homelessness' so that Rhys's characters, and often Rhys herself, become 'Guerrillas,' or 'outsider personas' that 'bridge the gap' between a Eurocentric self and Other, between Britain and the Caribbean (see, for example, Sheehan 142, and Thomas, Worlding of Jean Rhys 1). But in a manner similar to that which Hélène Cixous asserts in her essay, 'My Algeriance,' I think that Rhys and her most famous character tremble before, tremble on the verge of, identity; 'Passport,' says Cixous:

I cannot look at it without trembling for fear of being unmasked, because it is a fake, always has been.

Lie, forgery, use of forgery, in spite of myself with my consent. 
It is this verb to be that has always bothered me. What are you? Are you French? Who am I? Am I her? And to answer with a word or a cross in the box, when I would need one hundred or a blank. (206)

Just as Cixous cannot begin to answer, cannot stop answering, this question, 'Who am I?' Rhys and the characters of her fiction appear to suffer from a simultaneous lack and multiplicity of selfhood, an irreducibility of identity, an exotic, unmappable self.

This essay seeks to trouble the traditional understanding of Rhys's 'homelessness' through a re-examination of the way in which the uncertain female identities of her fiction are tied to their geographical settings. This works towards a reading of Rhys's narratives as 'literature of the tropics,' describing not only, of course, the landscape within which and from which so many of them operate, but a literature of the unrecognised, the unmapped. The uncanny psychological and topographical landscapes of Rhys's fiction, I suggest, are infused by a simultaneous headiness and claustrophobia of language itself; to read Rhys is to experience the literary sensation of the tropics. Sue Thomas has pointed out that 'Rhys's textual strategy of rewriting "European tropes, forms, themes, myths and the ways in which these operate" is widely acknowledged in postcolonial and feminist criticism' (WJR 2). However, in this essay I seek to complicate traditional readings of Rhys's work that reassert her liminality and sense of unbelonging to propose that it is, paradoxically, the very affinity of her work with the unassimilable tropics that produces this 'outsider status.' The homelessness of Rhys's characters, therefore, may be seen as an attempt to engage with the Caribbean tropical environment about which Rhys so often wrote. By this I mean that Rhys's narratives figure a more ethical representation of the tropics and maintain her narrators and characters as outsiders precisely because she refuses to presume to possess or capture the space of the tropics in art. To return to my example of the short story, 'I Used to Live Here Once,' Thorunn Lonsdale’s critical interpretation describes a typical reading of Rhys’s work which asserts that for this woman to recognise herself as a ghost is

... a metaphorical depiction perhaps of Rhys's memories for a place that was no longer her own and had, in fact, never really been by virtue of her relationship to it as a white Creole. The Caribbean was for Rhys a place where she could never truly feel at home and, although she did not have the same disdain for it as England, she felt something of an outsider. (4)

However, I suggest that this failure to impinge upon the landscape, and moreover, the representation of the human self, rather than the natural world, as unanimated, figures a narrative desire to represent a kind of ecological independence. It is through this resistance of the colonial gaze that Rhys's tropics narrativise the similar condition of her female characters.

This model of Rhys's work demands, then, a more subtle reading of autobiographical statements that assert the author's sense of Otherness. In Smile, Please, she writes: I would never be part of anything. I would never really belong anywhere, and I knew it, and all my life would be the same, trying to belong, and failing. Always something would go wrong. I am a stranger and I always will be, and after all I didn't really care. Perhaps it's my fault, I really can't think far enough for that. But I don't like these people, I thought. I don't hate - they hate - but I don't love what they love. [...] I don't know what I want. And if I did I couldn’t say it, for I don't speak their language and I never will. (124) 
I suggest that it is in Rhys's modernism - a new expression of language and narrative - that she moves away from traditional modes of representing the tropical landscape, and instead seeks what I see as a more ethical figuration of the Caribbean in her work. Contrary to the desire of the European coloniser, Rhys's narratives refuse to penetrate the unknowable wilderness, and instead perform a respect for the landscape that will not subject it to the Romanticisation or Gothicisation of the European gaze.

Rhys's tropics are not simply a trope; rather, her work demands to be part of an ecocritical project that, as C. A. Cranston and Robert Zeller suggest, makes place 'matter' (7), or in Lawrence Buell's terms, describes 'what it means to be in communion with place' (cited in Cranston and Zeller 13). Rhys's texts recognise tropical landscapes as an unassailable mystery that cannot and will not be subsumed into an existing European plot. The tropics of Rhys's fiction might seem to be tropes because they are, in a sense, 'all surface,' offering up little more than that which the tourist gaze wants to see, but this is, I think, precisely because she insists on maintaining the secrecy, or internal reliability, of these landscapes. Thus Rhys's writing does not seek to know the tropics so much as to respect the impossibility of its representation precisely because of an ethical insistence on its simultaneous unknowability and connectedness, rather than its submissively exoticised externality, a concept which, in postcolonial terms, is a 'dangerous myth' of disconnection, suggesting that another environment is 'available for exploitation' (Bennett and Royle 143). In this way, Rhys's postcolonialism describes what Bill Ashcroft, Gareth Griffiths and Helen Tiffin term an 'oppositional “reading” of English cultural imperialism' that refutes such a discourse 'not simply on its thematic level but also within the rhetorical or tropological apparatus of its figural language' (cited in Thomas, 'Conflicted Textual Affliction' 287). In narratives like Rhys's novel Wide Sargasso Sea, and the short stories 'Mixing Cocktails' (1927) and 'The Insect World' (1976), not only do the elusive tropics escape binary relation to the legitimising gaze of European identity, but in the sense that, as Annette Kolodny notes, feminist ecocriticism describes 'how bound we still are by the vocabulary of a feminine landscape and the psychological patterns of regression and violation that it implies' (cited in Bennett and Royle 146), the tropics of Rhys's work also provide an ecofeminist model of this escape for her female protagonists.

Several of Rhys's works criticise the project of European colonisation in the Caribbean, most clearly characterised by the 'Imperial Road' which, in the late nineteenth and early twentieth centuries, sought to open up the interior of Dominica for British investment in agricultural expansion, to grow, for example, coffee, cocoa, and rubber. Thus in two stories from Sleep it Off, Lady (1976), and set in turn-of-the-century Dominica, 'Pioneers, Oh Pioneers,' and 'Heat,' the suggestion that the consequences of 'going native,' in the former, and cultural 'wickedness' in the latter, are respectively psychological collapse and natural disaster, is mocked. But this forms only a part of a wider project that, in 'The Insect World,' becomes more clearly an analysis of the Orientalist discourse which permeates the narrativisation of the non-Western landscape.

'The Insect World' is set in London, just after the Blitz of World War II. Audrey is almost twenty-nine, and terrified of growing old. After reading about 'jiggers' (a parasitic flea found in tropical climates) in a battered paperback called Nothing So Blue, Audrey begins to suffer from the hallucinatory fear that the Londoners around her are insects. The story begins intertextually, reading and writing itself as a reexamined narrative of the tropics as it simultaneously reads and writes the Orientalist misreading of its fictional intertext: Audrey began to read. Her book was called Nothing So Blue. It was set in the tropics. She started at the paragraph which described the habits of an insect called the jigger. 
Almost any book was better than life, Audrey thought. Or rather, life as she was living it. [...] And books could take her away. (Rhys, SOL 125)

The tropics in fiction here are first figured as a site of imaginative escape that bears little resemblance to the 'real' tropics: 'It was about damp, moist heat, birds that did not sing, flowers that had no scent' (127). 'The natives were surly,' 'there were the minute crawling unseen things that got at you as you walked along harmlessly,' and 'there was this horrible girl whom the hero simply had to make love to, though he didn't really want to, and when the lovely, cool English girl heard about it she turned him down' (128). For Audrey, reading during the war, the tropics are a space of horror even worse than, and thus mitigating the misery of, the unending war. In particular, the fear of infection and infestation by strange insects, alien beings, can be seen as a kind of xenophobia in which the real threat of the entomorphic 'doodle bugs' and 'fly bombs' is safely transferred to the foreign and exotic 'far away' of the Caribbean.

But what is perhaps most striking about the work of Nothing So Blue in Rhys's 'The Insect World' is the way in which the text works as a physical site of the writing of patriarchal and Eurocentric definition, and as an expression of the horror of infection not only by the tropical insect, but the tropical woman. When Audrey buys her second-hand books, '[s]he always wrote her name on the fly-leaf and tried to blot out any signs of previous ownership. But this book had been very difficult. It had taken her more than an hour to rub out the pencil marks that had been found all through it' (126-27), for throughout the book, its previous owner, 'Charles Edwin Roofe,' has questioned, mocked and marked the narrative, culminating in the 'shock[ing]' statement, '[w]omen are an unspeakable abomination,' written 'with such force that the pencil had driven through the paper' (127). This annotated copy of Nothing So Blue thus figures the compounding of Orientalist discourses about the tropics which are not only unable to be erased, but score through and misrepresent the tropical landscape. Moreover, Audrey's novel goes to extraordinary effort to write woman into this landscape precisely in order to cast her as an 'abominably' infectious monster, to make her other, to cross her out. Like Audrey's project of erasure, Rhys's text labours to undo the marks of the colonising pen.

A similar fear is present in Wide Sargasso Sea. It is worth noting that as soon as the unnamed male narrator (often referred to as Rochester) arrives in Jamaica, he is feverishly ill; he thus 'attributes his willingness to marry Antoinette and his failure to notice her "[l]ong, sad, dark alien eyes” prior to their wedding' to this fever (Gildersleeve 902).

She never blinks at all it seems to me. Long, sad, dark, alien eyes. Creole of pure English descent she may be, but they are not English or European either. And when did I begin to notice all this about my wife Antoinette? After we left Spanish Town I suppose. Or did I notice it before and refuse to admit what I saw? Not that I had much time to notice anything. I was married a month after I arrived in Jamaica and for nearly three weeks of that time I was in bed with fever. (Rhys, WSS 40)

As I have argued elsewhere, Rochester "repeatedly recalls this illness, describing it as having "left me too exhausted to appreciate [the island] fully," unable to "think or write coherently," and feeling that "I am not myself yet"' (Rhys, WSS 40; Gildersleeve 902). But it is here that the 'alien' and 'impure' characteristics of Antoinette become entwined with a fear of strange illness, of island infection; Rochester's desire for his wife, he later concludes, must be a result 
of obeah. The island, too, is described as possessing 'an alien, disturbing, secret loveliness' (Rhys, WSS 54). The tropical island and Antoinette herself become 'entwined in Rochester's mind,' so that both come to be seen as exotic and dangerous, but also capable of undermining his corporeal control and his superiority, and demonstrating the way in which, for Thomas, ... within European epistemologies of infection 'bodily and territorial invasions' dislocate a range of connected colonial binaries - self/other, white/black, temperate/tropical, civilisation/savagery; or figure a physical and moral contagion which may be brought 'home' from the tropics. ('CTA' 291)

Thus, for Rochester, the European coloniser of both island and woman, the tropics are figured as oppressive, invasive, and bewitching. Like his wife, the island is simultaneously desired and repulsive, and Rochester seeks to match what he describes as the 'hostil[ity]' of the forest (WSS 65), with an aggressive mission to know 'its secret. I'd find myself thinking, "What I see is nothing - I want what it hides - that is not nothing"' (54). For Antoinette, however, the tropical landscape is overwhelming. The wild garden of her childhood at Coulbri and its strangely zoomorphised plants - 'one was snaky looking, another like an octopus with long thin brown tentacles bare of leaves hanging from a twisted root' - which infect the air with their 'very sweet and strong' scent, is a place she avoids: 'I never went near it,' she admits (6). It is in these differing attitudes to the tropical landscape - the desire to know, and the respect for its boundaries - that Wide Sargasso Sea moves towards the ethical representation of the tropics. Antoinette's refusal to penetrate the forest is not, I argue, the maintenance of an Orientalised perspective that sees only the wild savagery of chaotic nature, but rather a restraint from invasion or mutual infection.

I want, finally, to turn to one of Rhys's earliest short stories 'Mixing Cocktails,' for in both form and content, this text at once writes the unknowability of the tropics, and uses this landscape to demonstrate the differànce of its young female narrator. In this lyrical story very little happens: the little girl swings on a hammock on the verandah, and describes her morning, midday and afternoon dreams, influenced by the changing heat, the wind, and the colours of the ocean. Like Rochester in Wide Sargasso Sea, she is susceptible to the changing moods of the landscape, but for this child, her affinity with the tropics is figured as a struggle between her own, honest reading of her surroundings, and the 'legitimising' gaze of her white Creole family and a visiting English aunt. Thus, she at first dreams of finding treasure, for Dominica, she thinks, is a 'wild place [...]. Savage and lost. Just the place for Morgan to hide his treasure in' (Rhys, Tigers are Better-Looking 174). But this is quickly questioned, for while many of her descriptions of the sky and the sea are restricted to a tourist gaze which can only see and repeat the landscape in terms of a superlative 'blue,' as Thomas has noted (WJR 55), the narrator does admit that 'It was very difficult to look at the sea in the middle of the day. The light made it so flash and glitter: it was necessary to screw the eyes up tight before looking' (Rhys, TBL 174). It is in this sense that Rhys's work forms an important development of more traditional postcolonial writing produced since the nineteenth century. In Joseph Conrad's Heart of Darkness (1899), for example, the flash and glitter of the river in that novel is typically read as a symbolic figuration of the way in which the Congo hides its 'true' nature from its invaders. The river is not simply dark, but rather, hidden behind its blinding veil. Rhys's story takes this a step further, for even by simply exposing the failure of her family and other 'outsiders' to see beyond the blue of the traditional tourist gaze, Rhys's narrator recognises the 'difficult[y]' of really 'look[ing]' at the tropical landscape. Through squinted eyes, Rhys's narrator tries to see the ocean as it really is, as a glittering, lightreflecting veil over its 'secrets,' a bright blinding or deflection, not as an easily-read, 
transparent blue. The difference between the narrator of 'Mixing Cocktails' and Rochester of Wide Sargasso Sea, moreover, is that the former does not exhibit a desire to know or possess those secrets; rather, she is content to accept the tropics on its own terms.

It is here that the narrator finds an affinity with the tropics, as her thoughts, like the landscape, are colonised by her family: 'So soon,' she thinks, 'does one learn the bitter lesson that humanity is never content just to differ from you and let it go at that. Never. They must interfere, actively and grimly, between your thoughts and yourself - with the passionate wish to level up everything and everybody' (Rhys, TBL 174). This desire for unity between the 'inner' and 'outer' self, between one's 'thoughts' and the way one is viewed by others, is learned from the way in which the tropical landscape is repeatedly misread by the colonising gaze. Although the narrator of 'Mixing Cocktails' and the female characters of Rhys's fiction do admit their failure to completely know or to see the tropics, they do not seek, like the colonisers, to rectify this through possession or exploitation; rather, the female characters of Rhys's tropical landscapes respect this state of unknowing because they too experience a kind of shadowy desire to maintain a unity of self, without 'interfere[nce].' Thus, while Rhys's female characters at times seem to express a sense of frustration at their exclusion from established boundaries of identity, I think they finally revel in this independence; it is this they seem to recognise in the tropical landscape. The narrator of 'Mixing Cocktails,' then, will not claim to read or to represent the Other precisely because she understands the limits of her knowing.

As Sylvia M. Schomburg-Scherff points out, Rhys is then like other Caribbean novelists in her consciousness 'of the fact that all our perceptions, ways of thinking and representations are bound to a specific standpoint (in, for example, time, place and gender)' (368). Although it has limits (the maintenance of a binary structure, for example), this position is nevertheless always more ethical than the urge to colonise and contain. And while Thomas is right to suggest that this story 'centralises the gaze of the white Creole narrator,' I think Rhys is using that position to highlight another kind of infection: the infiltration of the European discourse of the Other (WJR 61). In 'Mixing Cocktails,' Rhys subverts the power of that discourse to articulate both the tropics and the female characters. In a narrative sense, this is most clearly seen in the striking use of ellipses throughout the story, not entirely unusual in her work, but in this story extraordinarily prominent, and signifying in their Modernist fragmentation a 'strategic and mimetic' (Linett 439) impossibility of completely narrativising the Other (both tropics and woman), as well as the power of the psychological and topographical landscape to escape simple troping. Thus the conflation of narrator, text and landscape here seems to me to describe a desire for independence, a resistance to being mapped, rather than the sense of alienation or infection expressed in 'The Insect World' and Wide Sargasso Sea. The tropics of Rhys's narratives are a signifier of differànce, a space symbolic of her female characters' own sense of being unknowable, unmappable, but simultaneously eluding any sense in which they can be troped. Rhys does not presume to speak for the tropics, but rather learns from and incorporates its strategies of resistance into her narrativisation of gendered struggle.

\section{Works Cited}

Bennett, Andrew, and Nicholas Royle. An Introduction to Literature, Criticism and Theory. 4th ed. Harlow: Longman Pearson, 2009 
Cixous, Hélène. 'My Algeriance, in Other Words: To Depart Not to Arrive from Algeria.' 1997. Trans. Eric Prenowitz. Stigmata: Escaping Texts. Abingdon: Routledge, 1998. 204-31

Cranston, C.A., and Robert Zeller, ed. The Littoral Zone: Australian Contexts and their Writers. Amsterdam: Rodopi, 2007

Gildersleeve, Jessica. 'Gender, Memory and Illness in Jean Rhys’s Wide Sargasso Sea.' Encyclopaedia of Themes in Literature. Vol. 3. Ed. Jennifer McClinton-Temple. 3 vols. Library of World Literature. New York: Facts on File, 2010. 901-4

Linett, Maren. “"New Words, New Everything”: Fragmentation and Trauma in Jean Rhys.' Twentieth Century Literature 51.4 (2005): 437-66

Lonsdale, Thorunn. 'Displacing the Heroine: Location in Jean Rhys's Short Stories "Let them Call it Jazz," "Mannequin,” and "I Used to Live Here Once.”' Journal of the Short Story in English 29 (1997): 2-7

Rhys, Jean. Wide Sargasso Sea. 1966. Ed. Angela Smith. London: Penguin, 2000

---. Smile, Please: An Unfinished Autobiography. London: Andre Deutsch, 1979

---. Sleep it Off, Lady. New York: Harper \& Row, 1976

---. Tigers are Better-Looking, with a selection from The Left Bank. New York: Harper \& Row, 1968

Schomburg-Scherff, Sylvia M. 'Women Versions of Creole Identity in Caribbean Fiction: A Cultural-Anthropological Perspective.' A Pepper-Pot of Cultures: Aspects of Creolisation in the Caribbean. Ed. Gordon Collier and Ulrich Fleischmann. Amsterdam: Rodopi, 2003. 367-74

Sheehan, Tom. 'Jean Rhys’s Caribbean Space-Time.' Journal of Caribbean Literatures 4.3 (2007): $141-54$

Thomas, Sue. The Worlding of Jean Rhys. Westport, CT: Greenwood, 1999

---. 'Conflicted Textual Affliction: Jean Rhys’s “The Insect” and "Heat.”' A Talent(ed) Digger: Creations, Cameos, and Essays in Honour of Anna Rutherford. Ed. Hena Maes-Jelinek, Gordon Collier, and Geoffrey V. Davis. Amsterdam: Rodopi, 1996. 287-94

Wyndham, Francis, and Diana Melly, ed. Jean Rhys: Letters 1931-1966. Harmondsworth: Penguin 1984

Young, Robert J.C. Postcolonialism: A Very Short Introduction. Oxford: Oxford UP, 2003 